\title{
Callistemon linearis Schrad. and J.C. Wendl. Extracts Inhibit the Growth of Gram-Positive Bacteria but have no Effect on Gram Negative Bacteria
}

\author{
Getmore Chikowe', Lindiwe Mpala', Ian Edwin Cock ${ }^{1,2, *}$ \\ 'School of Environment and Science, Griffith University, 170 Kessels Rd, Nathan, Brisbane, Queensland, AUSTRALIA. \\ 2Environmental Futures Research Institute, Griffith University, 170 Kessels Rd, Nathan, Brisbane, Queensland, AUSTRALIA.
}

\begin{abstract}
Introduction: The development of multi-antibiotic resistant strains of bacteria has necessitated the search for new effective antibacterial therapies. Many Callistemon spp. were used traditionally to treat pathogenic illness and are rich in terpenoids with reported antibacterial activity. Despite this, the antibacterial activity of $C$. linearis leaf extracts has not been extensively examined. Methods: The ability of $C$. linearis leaf extracts to inhibit the growth of gram-negative and gram-positive bacterial species was investigated by disc diffusion and growth time course assays. The growth inhibitory activity was further quantified by MIC determination. Toxicity was determined using the Artemia franciscana nauplii bioassay. Results: The methanolic and aqueous $C$. linearis leaf extracts were good inhibitors of the growth of gram-positive bacteria yet were completely ineffective against gram-negative bacteria. The methanolic extract was a particularly good inhibitor of $B$. cereus and S. pyogenes growth, with MIC values of 610 and $354 \mu \mathrm{g} / \mathrm{mL}$ respectively. The aqueous extract was also a good inhibitor of these bacteria (MICs of 927 and $660 \mu \mathrm{g} / \mathrm{mL}$ respectively). Whilst the extracts also inhibited the growth of $S$. aureus and $S$. epidermidis, the MIC values (in the range $1200-1500 \mu \mathrm{g} / \mathrm{mL}$ ) were indicative of moderate inhibitory activity. The methanolic extracts were further investigated by
\end{abstract}

growth time course assays that showed significant growth inhibition within $1 \mathrm{~h}$ of exposure. All extracts were determined to be nontoxic in the Artemia franciscana nauplii bioassay, indicating their safety for the treatment of gram-positive bacterial infections. Conclusion: The lack of toxicity of the C. linearis leaf extracts and their growth inhibitory bioactivity against the gram-positive bacteria indicate their potential in the development of new antibiotic chemotherapies.

Key words: Myrtaceae, Bottlebrush trees, Traditional medicine, Antibacterial, Antibiotic resistant bacteria, Rheumatic fever, Streptococcus pyogenes, Bacillus cereus

\section{Correspondence:}

Dr. Ian Edwin Cock

School of Environment and Science and Environmental Futures Research Institute Griffith University, 170 Kessels Rd, Nathan, Brisbane, Queensland, AUSTRALIA.

E-mail: I.Cock@griffith.edu.au

Phone no: +61737357637

DOI: 10.5530/pc.2019.2.10.

\section{INTRODUCTION}

The discovery of penicillin by Alexander Flemming in 1928 changed the way bacterial infections were treated and has resulted in substantially decreased mortalities towards many pathogenic infections. That discovery resulted in a major paradigm shift in the way that medical science sought to develop new antibiotic chemotherapies. Since that time, research has focussed on screening for microbially derived antibiotic agents to provide the majority of our first-generation drugs. Despite many significant advances in the treatment of pathogenic disease, bacteria have developed resistance to all of the antibiotics commonly used clinically. ${ }^{1}$ Several medicinally important bacterial pathogens have become either extremely (XDR) or totally drug resistant (TDR) to common clinically used antibiotics $^{1}$ and there are now limited therapeutic options for the diseases caused by these pathogens. This problem is expected to worsen in the future as bacteria exchange resistance genes and more strains become multi-drug resistant (MDR). The development of alternative antibacterial treatment modalities has become crucial and is considered by the World Health Organisation (WHO) to be one of the most serious challenges facing medical science. ${ }^{2}$ For a number of reasons reviewed elsewhere, ${ }^{1}$ it is unlikely that the previous methods of antibiotic discovery/ development will be as successful in the future and new treatment modalities are urgently required.

Traditional medicines and herbal remedies have great potential for antimicrobial drug development and there has recently been a substantial increase in interest in this field. ${ }^{3-5}$ The genus Callistemon (family Myrtaceae) consists of 34 species endemic to Australia. Some species have also been introduced to other areas such as USA ${ }^{6}$ and Africa ${ }^{7}$ where they are often considered to be invasive species. They are closely related to Mela- leucas which have similar leaf and flower morphology. ${ }^{8,9}$ Callistemons are commonly referred to as 'bottlebrushes' due to the appearance of their flowers. They occur naturally in temperate regions of Australia, particularly on the east and south-west coasts. Callistemon flowers were used as a food source by Australian Aborigines. The flowers were sucked for their nectar or used to make sweet drinks. ${ }^{10}$ They also had roles as traditional bush medicines for Australian Aborigines. ${ }^{11,12}$ The leaves were used to cure respiratory tract infections. Unfortunately most of our understanding of the antimicrobial potential of Australian Callistemon species is anecdotal with few species being thoroughly studied. It has been postulated that terpenes in the leaves may be responsible for the efficacy of Callistemons in therapeutic treatments. ${ }^{12}$ A recent report has demonstrated the antibacterial activity of a related Callistemon species (Callistemon rigidus). ${ }^{13}$ Studies within our laboratory have also found antibacterial activity in methanolic extracts of Callistemon citrinus and Callistemon salignus leaves and flowers against multiple bacteria. ${ }^{14,15}$

Despite this, many Callistemon spp. are yet to be thoroughly evaluated for antibacterial activity. Callistemon linearis Schrad. and J.C. Wendl. (synonyms Callistemon rigidus R.Br.; Melaleuca linearis Schrad. and J.C. Wendl.; Callistemon pinifolia J.C. Wendl.; Callistemon lanceolatus (Sm.) Sweet; commonly known as narrow-leaved bottlebrush) is a member of family Myrtaceae. It produces bright red flowers (Figure 1a) and has lanceolate leaves (Figure $1 \mathrm{~b}$ ) as a defining characteristic of the species. This species is endemic to the eastern states of Queensland and New South Wales in Australia. Some previous studies have reported antibacterial activity for this species against a several bacterial species. ${ }^{16}$ Whilst that study reported antibacterial activity against all of the species that it 


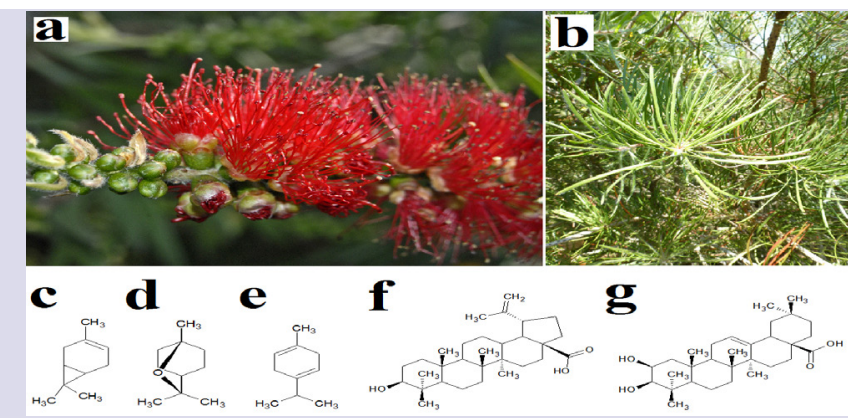

Figure 1: C. linearis (a) flower and (b) leaves, as well as the phytochemical compounds (c) 3-carene, (d) 1, 8-cineole, (e) $\gamma$-terpinene, (f) betulinic acid and (g) 2,3-dihydroxy olean-12-en-28-oic acid.

tested, it did not determine MIC values. A comparison of the potency of the extracts with other studies is therefore not possible. Further studies have examined the phytochemical composition of $C$. linearis leaves and have been reported to be particularly rich in the monoterpenoids 3 -carene (Figure 1c), 1, 8-cineole (Figure 1d) and $\gamma$-terpinene (Figure 1e). ${ }^{17}$ They are also rich in triterpenoids including betulinic acid (Figure 1f) and 2,3-dihydroxy olean-12-en-28-oic acid (Figure 1g). ${ }^{18}$ Interestingly, many terpenoids have potent antibacterial activity ${ }^{19,20}$ and this species may therefore be useful in blocking bacterial infections. The current study was undertaken to screen of $C$. linearis leaf extracts for the ability to inhibit the growth of a panel of gram-positive and gram-negative bacterial pathogens.

\section{MATERIALS AND METHODS}

\section{Plant Collection and Extraction}

Callistemon linearis Schrad. and J.C. Wendl. leaves were obtained from verified trees on the southside of Brisbane, Australia. The leaf samples were dried in a Sunbeam food dehydrator, ground to a coarse powder and stored at $-30^{\circ} \mathrm{C}$ until use. A volume of $50 \mathrm{~mL}$ of $\mathrm{AR}$ grade methanol (Ajax Fine Chemicals, Australia) or sterile deionised water was added to individual $1 \mathrm{~g}$ masses of the plant material and extracted for $24 \mathrm{hrs}$ at $4{ }^{\circ} \mathrm{C}$ with gentle shaking. The extract was filtered through filter paper (Whatman No. 54) under vacuum, followed by lyophilisation. The resultant pellets were weighed to determine the extraction yield and subsequently dissolved in $10 \mathrm{~mL}$ sterile deionised water (containing 1\% DMSO). The extracts were passed through $0.22 \mu \mathrm{m}$ filter (Sarstedt) and stored at $4^{\circ} \mathrm{C}$ until use.

\section{Qualitative Phytochemical Studies}

Phytochemical analysis of the $C$. linearis leaf extracts for the presence of saponins, phenolic compounds, flavonoids, phytosteroids, triterpenoids, cardiac glycosides, anthraquinones, tannins and alkaloids was conducted by standard assays. ${ }^{21-23}$

\section{Antibacterial Screening}

\section{Test Microorganisms}

All media was purchased from Oxoid Ltd., Australia. The reference strains of E. coli (ATCC157293), Klebsiella pneumoniae (ATCC31488), Proteus mirabilis (ATCC21721) and Streptococcus pyogenes (ATCC19615) were purchased from American Tissue Culture Collection (ATCC), USA. Clinical isolate microbial strains of Aeromonas hydrophilia, Alcaligenes feacalis, Bacillus cereus, Citrobacter freundii, Pseudomonas fluorescens,
Salmonella newport, Serratia marcescens, Shigella sonneii, Staphylococcus aureus and Staphylococcus epidermidis strains were obtained from Ms Michelle Mendell and Ms Jane Gifkins, Griffith University. All stock cultures were subcultured and maintained in nutrient broth at $4^{\circ} \mathrm{C}$.

\section{Evaluation of Antimicrobial Activity}

Antimicrobial activity of the $C$. linearis leaf extracts was determined using a modified disc diffusion assay. ${ }^{24-26}$ Briefly, $100 \mu \mathrm{L}$ of the each bacterial suspension in log phase was spread onto individual nutrient agar plates and the extracts were tested for antibacterial activity using $6 \mathrm{~mm}$ sterilised filter paper discs. The discs were each infused with $10 \mu \mathrm{L}$ of the individual plant extract, allowed to dry and placed onto the inoculated plates. The plates were allowed to stand at $4^{\circ} \mathrm{C}$ for $2 \mathrm{~h}$ before incubation at $37^{\circ} \mathrm{C}$ for $24 \mathrm{~h}$. The diameters of the zones of inhibition (ZOIs) were measured to the closest whole millimetre. Each assay was performed three times in triplicate $(n=9)$. Mean values $( \pm$ SEM) are reported in this study. Standard discs of ampicillin $(10 \mu \mathrm{g})$ and chloramphenicol $(10 \mu \mathrm{g})$ were obtained from Oxoid, Australia and were used as positive controls to compare antibacterial activity. Filter discs infused with $10 \mu \mathrm{L}$ of distilled water were used as a negative control.

\section{Minimum Inhibitory Concentration (MIC) Determination}

The minimum inhibitory concentration (MIC) of each extract against susceptible bacteria was determined as previously described. ${ }^{26,27}$ Briefly, the C. linearis leaf extracts were diluted in deionised water (1\% DMSO) and tested across a range of concentrations. Discs were individually infused with $10 \mu \mathrm{L}$ of each extract, allowed to dry and placed onto the inoculated plates. The assay was completed as outlined above and graphs of the ZOI versus ln concentration were plotted for each extract. Linear regression was used to determine the MIC values of each extract.

\section{Bacterial Growth Time Course Assay}

Bacterial growth time course studies were performed as previously described. ${ }^{28}$ Briefly, $3 \mathrm{~mL}$ of the gram-positive bacterial species in nutrient broth were individually added to $27 \mathrm{~mL}$ nutrient broth containing $3 \mathrm{~mL}$ of $10 \mathrm{mg} / \mathrm{mL}$ of the extract to give a final extract concentration of $1000 \mu \mathrm{g} /$ $\mathrm{mL}$ in the assay. The tubes were incubated at $37^{\circ} \mathrm{C}$ with gentle shaking. The optical density was measured hourly at $550 \mathrm{~nm}$ for a $6 \mathrm{~h}$ incubation period. Control tubes were incubated under the same conditions but without the extract. All assays were performed in triplicate.

\section{Toxicity Screening}

\section{Artemia franciscana Nauplii Toxicity Screening}

Toxicity was tested using an adapted Artemia franciscana nauplii lethality assay. ${ }^{29-31}$ Briefly, A. franciscana nauplii were incubated in the presence of the extracts, reference toxin $(1 \mathrm{mg} / \mathrm{mL}$ potassium dichromate) or artificial seawater (negative control) at $25 \pm 1^{\circ} \mathrm{C}$ under artificial light. All treatments were performed three times in triplicate $(n=9)$. The number of dead were counted in each well at $24 \mathrm{~h}$ and $48 \mathrm{~h}$. At the completion of the $48 \mathrm{~h}$ exposure period, the remaining live nauplii were sacrificed and the total number of nauplii in each well were counted and used to calculate the $\%$ mortality per well. LC $_{50}$ values were calculated for each treatment using probit analysis.

\section{Statistical Analysis}

Data are expressed as the mean \pm SEM of three independent experiments with internal triplicates $(n=9)$. One-way ANOVA was used to calculate statistical significance between control and treated groups, with a $P$ value $<0.01$ considered to be statistically significant. 


\section{RESULTS}

\section{Liquid extraction yields and qualitative phytochemical screening}

Extraction of $1 \mathrm{~g}$ of dried and powdered C. linearis leaves with methanol and water yielded 438 and $325 \mathrm{mg}$ of extracted material respectively (Table 1). The extracts were resuspended in $10 \mathrm{~mL}$ of deionised water (containing 1\% DMSO), resulting in an extract concentration shown in Table 1. Qualitative phytochemical studies showed that both extracts had similar phytochemical profiles. Both contained high levels of phenolic compounds and flavonoids, as well as moderate levels of triterpenoids and saponins. Lower levels of phytosterols, alkaloids and tannins were also detected. Cardiac glycosides and anthraquinones were completely absent or below the detection thresholds for these assays.

\section{Antimicrobial Activity}

To determine the growth inhibitory activity of the C. linearis leaf extracts, aliquots $(10 \mu \mathrm{L})$ of each extract were screened in the disc diffusion assay. The $C$. linearis leaf extracts were ineffective at inhibiting the growth of all of the gram-negative bacterial species tested (Figure 2). In contrast, both positive control antibiotics (ampicillin and chloramphenicol) were effective growth inhibitors, with ZOI's of up to $16 \mathrm{~mm}$ (chloramphenicol against E. coli). A much different trend was noted against the gram-positive bacterial species. Indeed, the methanolic and aqueous extracts inhibited the growth of all gram-positive bacteria. The methanolic extract was a better $B$. cereus growth inhibitor than was the aqueous extract (Figure 3 ). Indeed, the methanolic extract produced ZOIs that were only slightly smaller than the ampicillin and chloramphenicol controls. This is noteworthy as both of these controls were tested at relatively high doses $(10 \mu \mathrm{g} /$ disc $)$. Furthermore, the control antibiotics are pure compounds, whereas the extracts are crude mixtures and the active compound(s) would be expected to be a minor $\%$ of the overall extracts mass. Therefore, these extracts may be particularly promising as targets for antibiotic drug discovery.

The methanolic and aqueous extracts were also effective inhibitors of $S$. aureus (Figure 4) and S. epidermidis (Figure 5) growth, albeit with substantially smaller ZOIs noted. As noted for B. cereus, the methanolic extract was a more potent inhibitor of the Staphylococcus spp. growth (as judged by ZOI). However, the size of these ZOIs is indicative of only

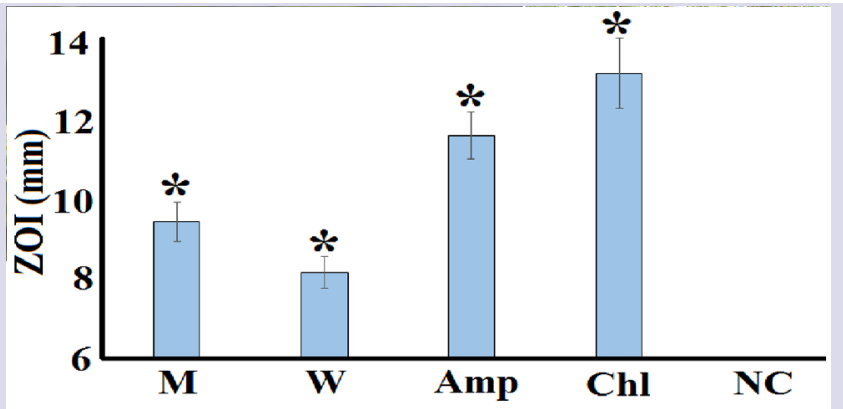

Figure 3: Growth inhibitory activity of $C$. linearis leaf extracts and reference antibiotics against $B$. cereus clinical isolate strain measured as ZOIs $(\mathrm{mm}) \pm$ SEM. Ampicillin (Amp) and chloramphenicol (Chl) standard discs $(10 \mu \mathrm{g})$ were used as positive controls. $\mathrm{NC}=$ negative control. All assays were completed three times, each with internal triplicates $(n=9)$ and the results are expressed as mean zones of inhibition $(\mathrm{mm}) \pm \mathrm{SEM} .{ }^{*}$ indicates values signidicantly different to the untreated control $(P<0.01)$.

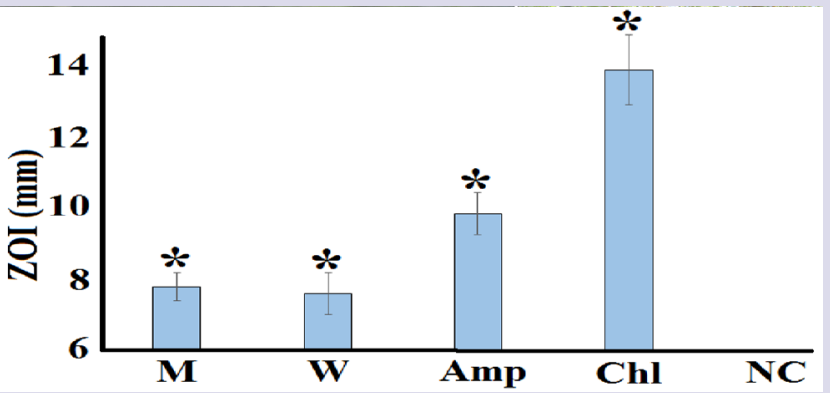

Figure 4: Growth Inhibitory activity of $C$. linearis leaf extracts and reference antibiotics against $S$. aureus clinical isolate strain measured as ZOls $(\mathrm{mm}) \pm$ SEM. Ampicillin (Amp) and chloramphenicol (Chl) standard discs $(10 \mu \mathrm{g})$ were used as positive controls. $\mathrm{NC}=$ negative control. All assays were completed three times, each with internal triplicates $(n=9)$ and the results are expressed as mean zones of inhibition $(\mathrm{mm}) \pm$ SEM. * indicates values signidicantly different to the untreated control $(P<0.01)$.

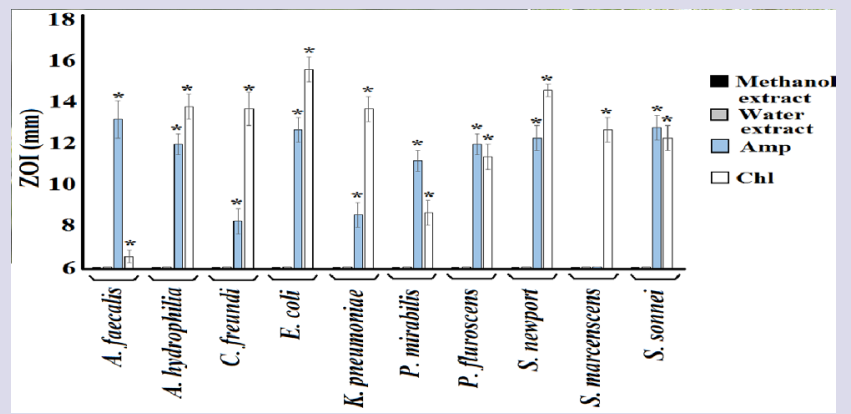

Figure 2: Growth Inhibitory Activity of $C$. linearis leaf extracts and reference antibiotics against gram-negative bacterial species measured as ZOls $(\mathrm{mm}) \pm$ SEM. Ampicillin (Amp) and chloramphenicol (Chl) standard discs $(10 \mu \mathrm{g})$ were used as positive controls. All assays were completed three times, each with internal triplicates $(n=9)$ and the results are expressed as mean zones of inhibition $(\mathrm{mm}) \pm$ SEM. * indicates values signidicantly different to the untreated control $(P<0.01)$.

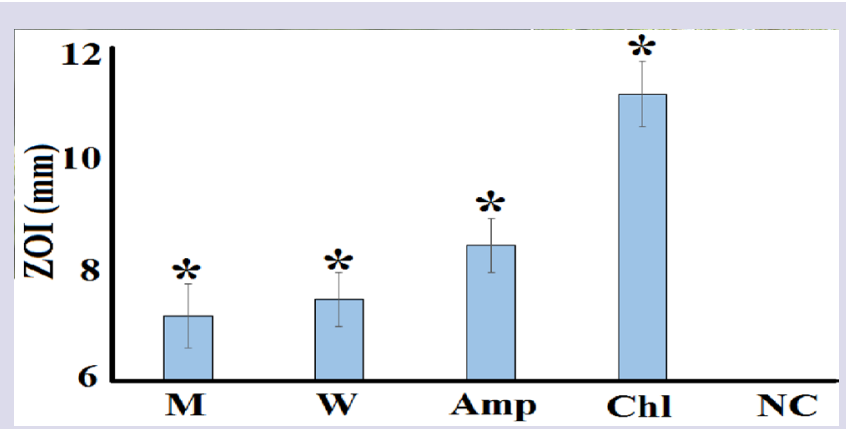

Figure 5: Growth inhibitory activity of $C$. linearis leaf extracts and reference antibiotics against $S$. epidermidis clinical isolate strain measured as ZOls ( $\mathrm{mm}) \pm$ SEM. Ampicillin (Amp) and chloramphenicol (Chl) standard discs $(10 \mu \mathrm{g})$ were used as positive controls. $\mathrm{NC}=$ negative control. All assays were completed three times, each with internal triplicates $(n=9)$ and the results are expressed as mean zones of inhibition $(\mathrm{mm}) \pm$ SEM. * indicates values signidicantly different to the untreated control $(P<0.01)$. 
moderate inhibitory activity. In contrast, the methanolic and aqueous extracts were particularly good inhibitors of $S$. pyogenes growth (Figure 6). Indeed, ZOIs of 16 and $12.3 \mathrm{~mm}$ were noted for the methanolic and aqueous extracts respectively against $S$. pyogenes. This bacterium was quite resistant to ampicillin, with a ZOI of approximately $7 \mathrm{~mm}$. The ZOIs of both extracts were also substantially bigger than that of the chloramphenicol control $(\sim 9 \mathrm{~mm})$ indicating that these extracts have good inhibitory activity against resistant $S$. pyogenes strains. As $S$. pyogenes can cause a wide variety of diseases including pharyngitis, impetigo and rheumatic fever depending on the tissue that it infects, these extracts may be particularly useful as targets for antibiotic discovery.

The antimicrobial efficacy was further quantified by determining the MIC value. The methanolic and aqueous extracts were particularly good inhibitors of $S$. pyogenes growth, with MIC values of 354 and $660 \mu \mathrm{g} / \mathrm{mL}$ respectively. Both extracts were also good inhibitors of $B$. cereus growth, with MIC values of 610 and $927 \mu \mathrm{g} / \mathrm{mL}$ respectively. Higher MIC values $(1200-1500 \mu \mathrm{g} / \mathrm{mL})$ were noted against both Staphylococcus spp. Whilst these MIC values demonstrate that the C. linearis leaf extracts have potential in the control of Staphylococcus spp. infections, they indicate only moderate potency.

\section{Bacterial Growth Time Course Assay}

The antibacterial activity of the $C$. linearis leaf methanolic and aqueous leaf extracts was further investigated against the four gram-positive bacterial species by bacterial growth time course assays in the presence and absence of the extracts. The starting concentration of the extract used in these assays was $1000 \mu \mathrm{g} / \mathrm{mL}$. The $C$. linearis leaf methanolic and aqueous leaf extracts both significantly inhibited B. cereus within 1 h of exposure, indicating a rapid antimicrobial action. The absorbance of the $B$. cereus culture (And thus the bacterial growth) remained substantially lower than the untreated control for the entire $6 \mathrm{~h}$ incubation period. Indeed, the turbidity had not significantly increased throughout the 6 h growth period, indicating that the extracts may be bacteriocidal at the concentrations tested (Figure 7a). The methanolic and aqueous extracts were also was rapid in its inhibition of S. aureus (Figure 7b) and S. epidermidis (Figure 7c) growth, with a significant decrease in bacterial growth also noted within the first hour of incubation. However, in contrast to the inhibition of B. cereus growth, the inhibition of the Staphylococcus spp. growth had returned to similar levels to that of the untreated control by the end of the $6 \mathrm{~h}$ incubation period (as judged by turbidity). This may indicate that the aqueous $C$. linearis leaf methanolic and aqueous leaf extracts had bacteriostatic effects at the tested concentration, rather than bactericidal effects. The inhibition of S. pyogenes growth (Figure 7d) followed similar trends to those noted for B. cereus, indicating that the extracts may be bactericidal at the tested concentration.

\section{Quantification of Toxicity}

The toxicity of the C. linearis leaf extracts was initially tested at $2 \mathrm{mg} /$ $\mathrm{mL}$ in the A. franciscana nauplii bioassay (Figure 8 ). The mortality in the presence of all extracts was not significantly different to that of the untreated control at $24 \mathrm{~h}$ and thus were deemed to be non-toxic. Extracts with $24 \mathrm{~h} \mathrm{LC}_{50}$ values $>1000 \mu \mathrm{g} / \mathrm{mL}$ have previously been defined as nontoxic. ${ }^{30,31}$ In contrast, the potassium dichromate positive control induced substantial mortality within $4 \mathrm{~h}$ (Results not shown), with $100 \%$ mortality induction seen by $24 \mathrm{~h}$. The mortality induction remained low for the C. linearis leaf extracts at $48 \mathrm{~h}$. Indeed, the $\%$ mortality induction was substantially $<50 \%$ for all extracts at all times tested and therefore it was not possible to determine $\mathrm{LC}_{50}$ values for any of the $C$. linearis leaf extracts (Table 2).

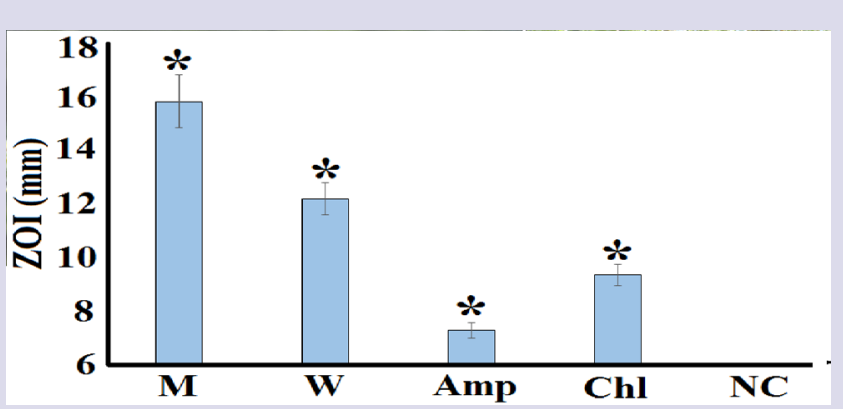

Figure 6: Growth inhibitory activity of $C$. linearis leaf extracts and reference antibiotics against S. pyogenes (ATCC19615) measured as ZOls $(\mathrm{mm}) \pm \mathrm{SEM}$. Ampicillin (Amp) and chloramphenicol (Chl) standard discs $(10 \mu \mathrm{g})$ were used as positive controls. $\mathrm{NC}=$ negative control. All assays were completed three times, each with internal triplicates $(n=9)$ and the results are expressed as mean zones of inhibition $(\mathrm{mm}) \pm$ SEM. * indicates values signidicantly different to the untreated control $(P<0.01)$.
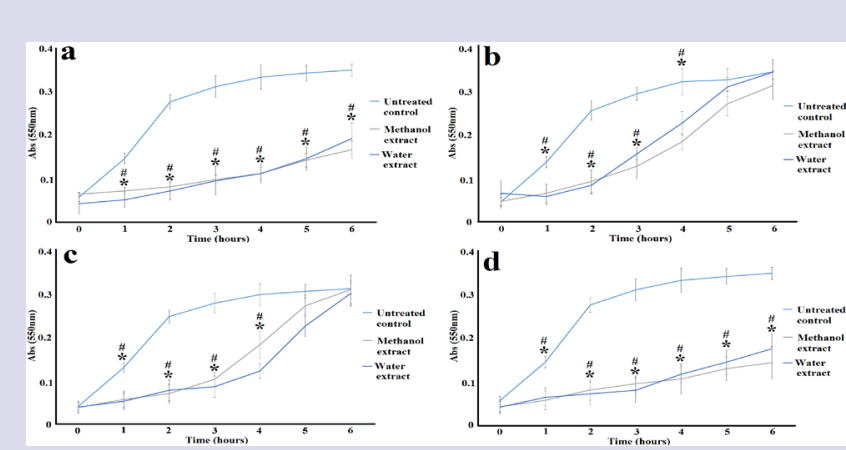

Figure 7: Bacterial growth curves for the $C$. linearis leaf methanolic extract against (a) B. cereus, (b) S. aureus, (c) S. epidermidis and (d) S. pyogenes. All bioassays were performed three times in triplicate $(n=9)$ and are expressed as mean \pm SEM. ${ }^{*}=$ methanolic extract results that are significantly different between the treated and the untreated control growth; \# = aqueous extract results that are significantly different between the treated and the untreated control growth $(P<0.01)$.

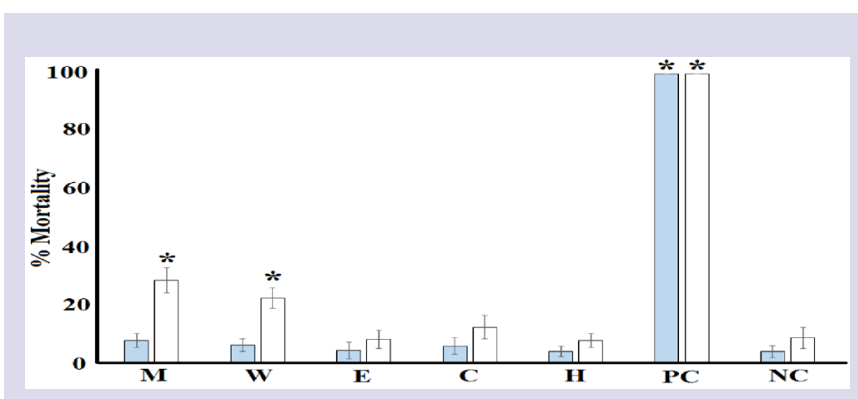

Figure 8: The Lethality of the C. linearis leaf extracts $(2000 \mu \mathrm{g} /$ $\mathrm{mL})$, Potassium dichromate control $(1000 \mu \mathrm{g} / \mathrm{mL})$ and seawater (negative control). Shaded bars represent the mortality induced by the $C$. linearis leaf extracts following $24 \mathrm{~h}$ exposure; open bars represent the mortality induced by the $C$. linearis leaf extracts following $48 \mathrm{~h}$ exposure. All bioassays were performed three times in triplicate $(n=9)$ and are expressed as mean \pm SEM. * indicates results that are significantly different to the untreated (seawater) control at the equivalent exposure time $(P<0.01) .{ }^{*}$ indicates values significantly different to the untreated control $(P<0.01)$. 
Table 1: The Mass of Dried Extracted Material, the Concentration after Resuspension in Deionised Water and Qualitative Phytochemical Screenings of the C. linearis Leaf Extracts.

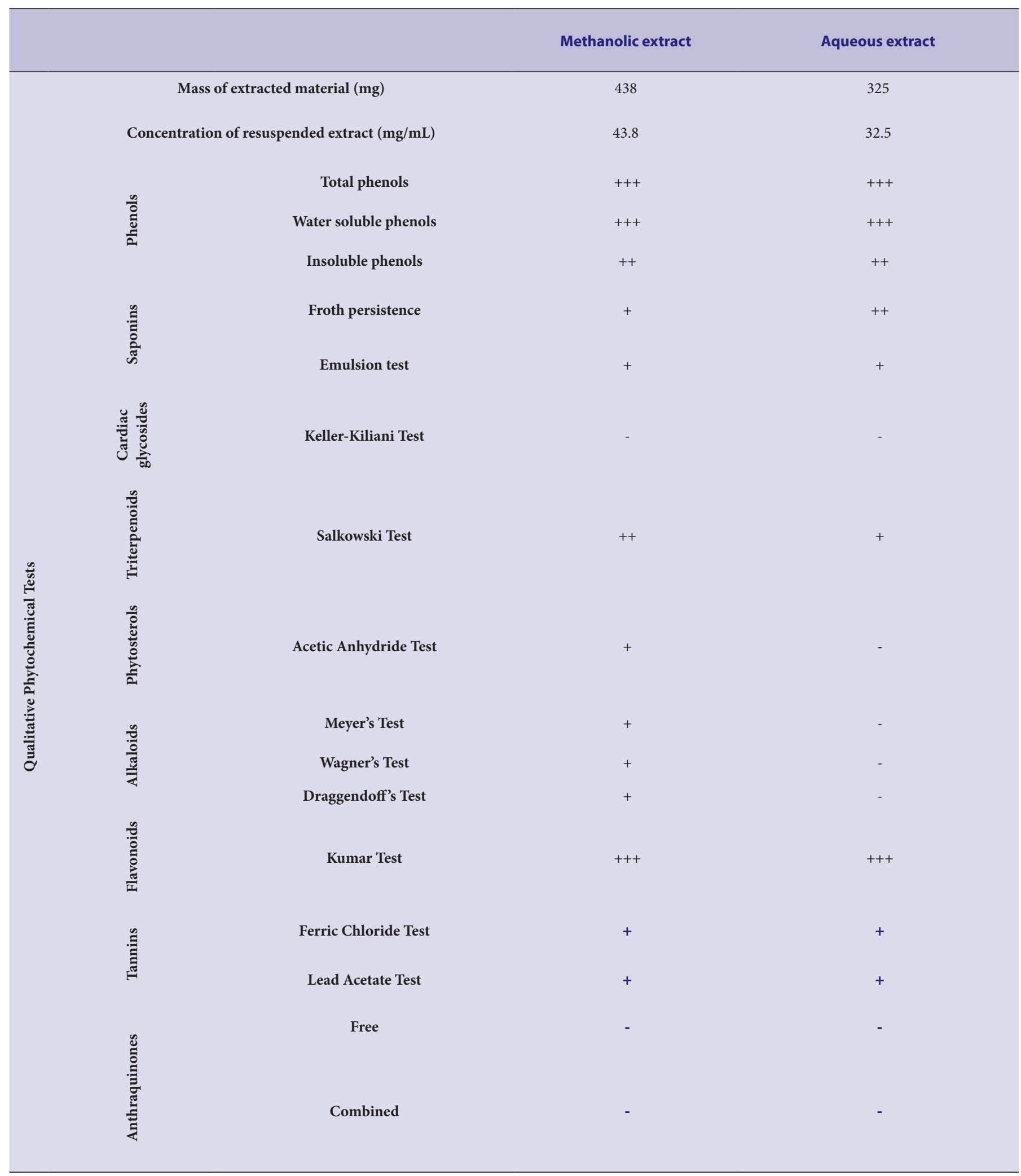

+++ indicates a large response; ++ indicates a moderate response; + indicates a minor response; - indicates no response in the assay. 


\section{DISCUSSION}

Despite the initial potency of many antibiotic chemotherapies, recent increases in bacterial resistance to many antibiotics has made the development of new antibiotic therapies a high priority. ${ }^{1}$ A parallel decrease in the introduction of new antibiotic therapies in recent years has further compounded this problem. As a result, interest in re-evaluating medicinal plants for new antibiotic chemotherapies has escalated substantially. ${ }^{32}$ Callistemon spp. are good candidates for the development of new antibacterial drugs as they were used by Australian Aborigines to treat bacterial infections. ${ }^{11,12}$ Furthermore, several studies have reported that Callistemon citrinus and Callistemon salignus leaf and flower extracts are potent inhibitors of multiple bacterial species. ${ }^{14,15}$ This study has extended these earlier studies by testing $C$. linearis against an extended panel of bacterial pathogens.

The greater susceptibility of Gram-positive bacteria to the C. linearis leaf extracts noted in this study is in agreement with previously reported results for South American, ${ }^{33,34}$ African ${ }^{35,36}$ and Australian ${ }^{37}$ plant extracts. Results within our laboratory have also confirmed the greater susceptibility of Gram-positive bacteria towards other Australian plant extracts. ${ }^{38-40}$ The Gram-negative bacterial cell wall outer membrane is thought to act as a barrier to many substances including antibiotics. ${ }^{41}$ The uptake of the Callistemon extract antibiotic compounds by gram-negative bacteria is presumably affected by the cell wall outer membrane. In contrast, other studies have demonstrated that Gram-negative bacteria are often more susceptible to plant extracts from different Australian plant species. ${ }^{42-44}$

Whilst an investigation of the phytochemistry of the C. linearis leaf extracts was beyond the scope of our study, high levels of polyphenolics and flavonoids, as well as moderate levels of triterpenoids and saponins were noted in the extracts in the qualitative phytochemical screening study. Lower levels of tannins were also detected. Flavonoids have well established bacterial growth inhibitory activities. ${ }^{19}$ For example, the flavonoids kaempferol and myricetin have potent growth inhibitory activity against a panel of bacteria. ${ }^{45}$ Similarly, quercetin, rutin and their

Table 2: Minimum Inhibitory Concentrations $(\mu \mathrm{g} / \mathrm{mL})$ of the C. linearis Leaf Extracts against each Bacterial Strain and LC ${ }_{50}$ Values $(\mu \mathrm{g} /$ $\mathrm{mL}$ ) against Artemia Nauplii.

\begin{tabular}{cccc}
\hline Organism & $\begin{array}{c}\text { Exposure } \\
\text { time (h) }\end{array}$ & $\begin{array}{c}\text { Methanolic } \mathrm{LC}_{50}(\mathrm{ug} / \mathrm{mL}) \\
\text { extract }\end{array}$ & Aqueous extract \\
\hline $\begin{array}{c}\text { B. cereus } \\
\text { (clinical isolate) }\end{array}$ & 24 & 610 & 927 \\
$\begin{array}{c}\text { S. aureus } \\
\text { (clinical isolate) }\end{array}$ & 24 & 1188 & 1355 \\
$\begin{array}{c}\text { S. epiedermidis } \\
\text { (clinical isolate) }\end{array}$ & 24 & 1463 & 1292 \\
$\begin{array}{c}\text { S. pyogenes } \\
\text { (ATCC19615) }\end{array}$ & 24 & 354 & 660 \\
& 24 & $\mathrm{CND}$ & $\mathrm{CND}$ \\
Artemia nauplii & 48 & $\mathrm{CND}$ & $\mathrm{CND}$ \\
\hline
\end{tabular}

Numbers indicate the mean MIC or $\mathrm{LC}_{50}$ values of three independent experiments in triplicate $(n=9)$. CND indicates that an $\mathrm{LC}_{50}$ could not be determined as the mortality did not exceed $50 \%$ at any concentration tested. corresponding glycosides inhibit the growth of Pseudomonas maltophilia and Enterobacter cloacae. ${ }^{46}$ The antimicrobial activity of terpenoids has also been extensively documented. Monoterpenoids including a-pinene, $\beta$-pinene, sabinene, mycrene, terpinene, limonene, piperitone and $\beta$-phellandrene inhibit the growth of a panel of bacteria including several antibiotic resistant strains of Enterobacteriaceae. ${ }^{19}$ Similarly, the antibacterial activities for several sesquiterpenoids including a-cubebene, copaene and caryophyllene have been reported. ${ }^{19}$ Furthermore, many tannin compounds have bacterial growth inhibitory activity. Gallotannins inhibit the growth of a broad spectrum of bacterial species ${ }^{47}$ through a variety of mechanisms including binding cell surface molecules including lipotoichoic acid and proline-rich cell surface proteins, ${ }^{48,49}$ and by inhibiting glucosyltransferase enzymes. ${ }^{50}$ Elligitannins are also highly potent inhibitors of bacterial growth, with MIC values as low as 62.5 $\mu \mathrm{g} / \mathrm{mL} .{ }^{47,49}$ Ellagitannins have also been reported to function via several antibiotic mechanisms including interaction with cytoplasmic oxidoreductases and by disrupting bacterial cell walls. ${ }^{47,49}$ Thus, it is likely that multiple compounds within the C. linearis leaf extracts are contributing to the antibacterial activity reported here.

The findings reported here also indicate that the extracts examined were non-toxicity $\left(\mathrm{LC}_{50}>1000 \mu \mathrm{g} / \mathrm{mL}\right.$ ) in the Artemia nauplii bioassay. Whilst toxicity was assessed in this study with the test organism A. franciscana, toxicity towards $A$. franciscana has previously been shown to correlate well with toxicity towards human cells for many toxins. ${ }^{30,31}$ However, further studies are required to determine whether this is also true for the $C$. linearis leaf extracts examined in these studies. The results of this study indicate that the $C$. linearis leaf extracts may be good candidates for antimicrobial drug discovery and further examination is warranted. Whilst the extracts examined in this report have potential as bacterial growth inhibitors, caution is needed before these compounds can be applied to medicinal purposes. Purification and identification of the bioactive components is needed to examine the mechanisms of action of these agents.

\section{CONCLUSION}

The growth inhibitory activity of the $C$. linearis leaf extracts against the gram-positive bacteria, particularly against $S$. pyogenes and their lack of toxicity indicate their potential for the treatment of all manifestations of streptococcal disease, including systemic treatment. Further studies aimed at the purification of the bioactive components are needed to examine the mechanisms of action of these agents.

\section{ACKNOWLEDGEMENT}

The authors are grateful to Michelle Mendell and Jane Gifkins of Griffith University for providing the clinical bacterial strains used in this study. Financial support for this work was provided by the Environmental Futures Research Institute and the School of Natural Sciences, Griffith University, Australia.

\section{CONFLICT OF INTEREST}

The authors report no conflicts of interest.

\section{ABBREVIATIONS}

DMSO: Dimethyl sulfoxide; $\mathbf{L C}_{50}$ : The concentration required to achieve $50 \%$ mortality; MIC: Minimum inhibitory concentration; ZOI: Zone of inhibition.

\section{REFERENCES}

1. Cheesman MJ, Ilanko A, Blonk B, Cock IE. Developing new antimicrobial therapies: Are synergistic combinations of plant extracts/compounds with conventional antibiotics the solution?. Pharmacognosy Reviews. 2017;11(22):57-72 DOI: 10.4103/phrev.phrev_21_17 
2. WHO. Antimicrobial Resistance. World Health Organization; 2016. Available from: http://www.who.int/mediacentre/factsheets/fs194/en/. [Cited on 2017 May 10].

3. Sirdaarta J, Matthews B, Cock IE. Kakadu plum fruit extracts inhibit the growth of the bacterial triggers of rheumatoid arthritis: Identification of stilbene and tannin components. Journal of Functional Food. 2015;17:610-20. DOI: 10.1016/j. jff.2015.06.019.

4. Ilanko A Cock IE. The interactive antimicrobial activity of contentional antibiotics and Petalostigma spp. Extracts against bacterial triggers of some autoimmune inflammatory diseases. Pharmacognosy Journal. 2019;11(2):292-309. DOI: $10.5530 /$ pj.2019.11.45.

5. Chowdhury AN, Ashrafuzzaman M, Ali H, Liza LN, Zinnah KMA. Antimicrobial activity of some medicinal plants against multi drug resistant human pathogens. Advances in Bioscience and Bioengineering. 2013;1(1):1-24.

6. Gilman EF. Calistemon rigidus, Fact sheet FPS-93, Environmental Horticulture Department, Institute of Food and Agricultural Sciences, University of Florida, USA. 1999.

7. Nel JL, Richardson DM, Rouget M, et al. A proposed classification of invasive alien plant species in South Africa: towards prioritising species and areas for management action. South African Journal of Science. 2004;100(1-2):53-64.

8. Wrigley J, Fagg M. Bottlebrushes, paperbark and teatrees, Angus and Robertson, Australia. 1993.

9. Elliot WR, Jones D. The Encyclopedia of Australian plants. Lothian Publishing Company Pty Ltd, Melbourne, Australia. 1982;2.

10. Nash D. Aboriginal plant use and technology. Australian National Botanic Gardens. ACT, Australia. 2000

11. Cock IE. Medicinal and aromatic plants - Australia, in Ethnopharmacology section, Biological, Physiological and Health Sciences, Encyclopedia of Life Support Systems (EOLSS), 2011. Developed under the Auspices of the UNESCO, EOLSS Publishers, Oxford, UK, (http://www.eolss.net).

12. Jirovetz L, Fleischhacker W, Buchbauer G, Ngassoum MB. Analysis of the essential oils of Callistemon rigidus (Myrtaceae) from Cameroun by GC/FID and GC/MS. Scientia Pharmaceutica. 1997;65(4):315-9.

13. Sanjai S, Charu G. Antimicrobial potential of Callestemon rigidus. Pharmaceutical Biology. 2006;44(3):194-201.

14. Cock IE. Antibacterial activity of selected Australian plant species. The Internet Journal of Microbiology. 2008;6:2.

15. Cock IE. Antimicrobial activity of Callistemon citrinus and Callistemon salignus methanolic extracts. Pharmacognosy Communications 2012;2(3):50-7. DOI: 10.5530/pc.2012.3.11

16. Haque A, Siddiqi MMA, Rahman AFMM, et al. Antimicrobial and cytotoxic activities of the crude extracts of Callistemon linearis. International Journal of Biosciences. 2013;3(3):129-33

17. Shukla $R$, Singh $P$, Prakash $B$, et al. Antifungal, aflatoxin inhibition and antioxidant activity of Callistemon lanceolatus (Sm.) Sweet essential oils and its major component 1,8-cineole against fungal isolates from chickpea seeds. Food Control. 2012;25(1):27-33.

18. Haque A, Siddiqi MMA, Rahman AM, et al. Isolation of betulinic acid and 2,3-dihydroxyolean-12-en-28-oic acid from the leaves of Callistemon linearis. Dhaka University Journal of Science. 2013;61(2):211-2.

19. Cock IE. The phytochemistry and chemotherapeutic potential of Tasmannia lanceolata (Tasmanian pepper): A review. Pharmacognosy Communications 2013;3(4):13-25. DOI: 10.5530/pc.2013.4.3

20. Cock IE. The genus Aloe: Phytochemistry and therapeutic uses including treatments for gastrointestinal conditions and chronic inflammation. In Novel Natural Products: Therapeutic Effects in Pain, Arthritis and Gastro-intestinal Diseases. 2015;179-235. DOI 10.1007/978-3-0348-0927-6_6

21. Winnett $V$, Sirdaarta J, White A, et al. Inhibition of Klebsiella pneumonia growth by selected Australian plants: natural approaches for the prevention and management of ankylosing spondylitis. Inflammopharmacology. 2017;25(2):223-35 DOI: 10.1007/s10787-017-0328-1

22. Sirdaarta J, Matthews B, Cock IE. Kakadu plum fruit extracts inhibit growth of the bacterial triggers of rheumatoid arthritis: Identification of stilbene and tannin components. Journal of Functional Foods. 2015;17:610-20. DOI: 10.1016/j. jff.2015.06.019

23. Mpala L, Chikowe G, Cock IE. No evidence of antiseptic properties and low toxicity of selected Aloe species. Journal of Pharmaceutical Negative Results. 2010;1(1):10-6. DOI: 10.4103/0976-9234.68869

24. Maen A, Cock IE. Inhibitory activity of Australian cullinary herb extracts against the bacterial triggers of selected autoimmune diseases. Pharmacognosy Communications. 2015;5(2):130-9. DOI: 10.5530/pc.2015.2.4

25. Sirdaarta J, Matthews B, Cock IE. Inhibitory activity of Kakadu plum fruit extracts against microbial triggers of rheumatoid arthritis: Identification of stilbene and tannin components. Journal of Functional Foods. 2015;17(1):610-20.

26. Sirdaarda J, Matthews B, White A, et al. GC-MS and LC-MS analysis of Kakadu plum fruit extracts displaying inhibitory activity against microbial triggers of multiple sclerosis. Pharmacognosy Communications. 2015;5(2):100-15. DOI: 10.5530/pc.2015.2.2

27. Kalt FR, Cock IE. Gas chromatography-mass spectroscopy analysis of bioactive
Petalostigma extracts: Toxicity, antibacterial and antiviral activities. Pharmacog Mag. 2014;10(Suppl 1):S37-49. DOI: 10.4103/0973-1296.127338

28. Cock IE. Antimicrobial activity of Acacia aulacocarpa and Acacia complanta methanolic extracts. Pharmacognosy Communications. 2012;2(1):66-71. DOI: 10.5530/pc.2012.1.12

29. Cock IE, Winnett V, Sirdaarta J, et al. The potential of selected Australian medicinal plants with anti-Proteus activity for the treatment and prevention of rheumatoid arthritis. Pharmacognosy Magazine. 2015;11(42 Suppl 1):S190-208. DOI: 10.4103/0973-1296.157734

30. Ruebhart DR, Wikramasinghe WA, Cock IE. Protective efficacy of the antioxidants vitamin $\mathrm{E}$ and Trolox against Microcystis aeruginosa and microcystin-LR in Artemia franciscana nauplii. Journal of Toxicology and Environmental Health Part A. 2009;72(24):1567-75.

31. Cock IE, Ruebhart DR. Comparison of the brine shrimp nauplii bioassay and the ToxScreen-Il test for the detection of toxicity associated with Aloe vera (Aloe barbadensis Miller) leaf extract. Pharmacognosy Research. 2009;1(2):98-101.

32. Aiyegoro OA, Okoh Al. Use of bioactive plant products in combination with standard antibiotics: Implications in antimicrobial chemotherapy. Journal of Medicinal Plants Research. 2009;3(13):1147-52.

33. Paz EA, Cerdeiras MP, Fernandez J, et al. Screening of Uruguayan medicinal plants for antimicrobial activity. Journal of Ethnopharmacology. 1995;45(1):6770 .

34. Mohanty S, Cock IE. Evaluation of the antibacterial activity and toxicity of Myrciaria caulifloria methanolic leaf and fruit extracts. Internet Journal of Microbiology. $2009 ; 7(2)$.

35. Cock IE, Vuuren VSF. Anti-Proteus activity of some South African medicinal plants: Their potential for the treatment and prevention of rheumatoid arthritis. Inflammopharmacology. 2014;22(1):23-36. DOI 10.1007/s10787-013-0179-3.

36. Cock IE, Vuuren VSF. The potential of selected some South African plants with anti-Klebsiella activity for the treatment and prevention of ankylosing spondylitis. Inflammopharmacology. 2014;23(1):21-35. DOI: 10.1007/s10787-014-0222-z

37. Palombo EA, Semple SJ. Antibacterial activity of traditional Australian medicinal plants. Journal of Ethnopharmacology. 2001;77(2-3):151-7.

38. Cock IE. Antimicrobial activity of Eucalyptus major and Eucalyptus baileyana methanolic extracts. Internet Journal of Microbiology. 2009;6(1):31.

39. Kalt FR, Cock IE. The medicinal potential of Australian native plants from Toohey Forest, Australia. South Pacific Journal of Natural Sciences. 2011;28:41-7.

40. Chikowe G, Mpala L, Cock IE. Antibacterial activity of selected Australian Syzygium species. Pharmacognosy Communications. 2013;3(4):77-83. DOI: 10.5530/pc.2013.4.11

41. Tortora GJ, Funke BR, Case CL. Microbiology: An Introduction, Benjamin Cummings, San Francisco. 2001.

42. Vesoul J, Cock IE. The potential of Bunya nut as an antibacterial food agent Pharmacognosy Communications. 2012;2(1):74-82.

43. Vesoul J, Cock IE. An examination of the medicinal potential of Pittosporum phylloraeoides: Toxicity, antibacterial and antifungal activities. Pharmacognosy Communications. 2011;1(2):8-17. DOI: 10.5530/pc.2012.1.13

44. Kukkonen L, Cock IE. An examination of the medicinal potential of Scaevola spinescens: Toxicity, antibacterial and antiviral activities. Pharmacognosy Research. 2011;3(2):85-94. DOI: 10.4103/0974-8490.81955

45. Cai L, Wu CD. Compounds from Syzygium aromaticum possessing growth inhibitory activity against oral pathogens. Journal of Natural Products. 1996;59(10):987-90.

46. Waage SK, Hedin PA. Quercetin 3-O-galactosyl-(1, 4, 6)-glucoside, a compound from narrow leaf vetch with antibacterial activity. Phytochemistry. $1985 ; 24(2): 243-5$.

47. Buzzini P, Arapitsas P, Goretti M, et al. Antimicrobial activity of hydrolysable tannins. Mini-Reviews in Medicinal Chemistry. 2008;8(12):1179-87.

48. Wolinsky LE, Sote EO. Isolation of natural plaque-inhibiting substances from 'Nigerian chewing sticks'. Caries Research. 1984;18(3):216-25.

49. Hogg SD, Embery G. Blood-group-reactive glycoprotein from human saliva interacts with lipoteichoic acid on the surface of Streptococcus sanguis cells. Archives in Oral Biology. 1982;27(3):261-8.

50. Wu-Yuan CD, Chen CY, Wu RT. Gallotannins inhibit growth, water-soluble glucan synthesis and aggregation of Streptococci mutans. Journal of Dental Research. $1988 ; 67(1): 51-5$ 
PICTORIAL ABSTRACT
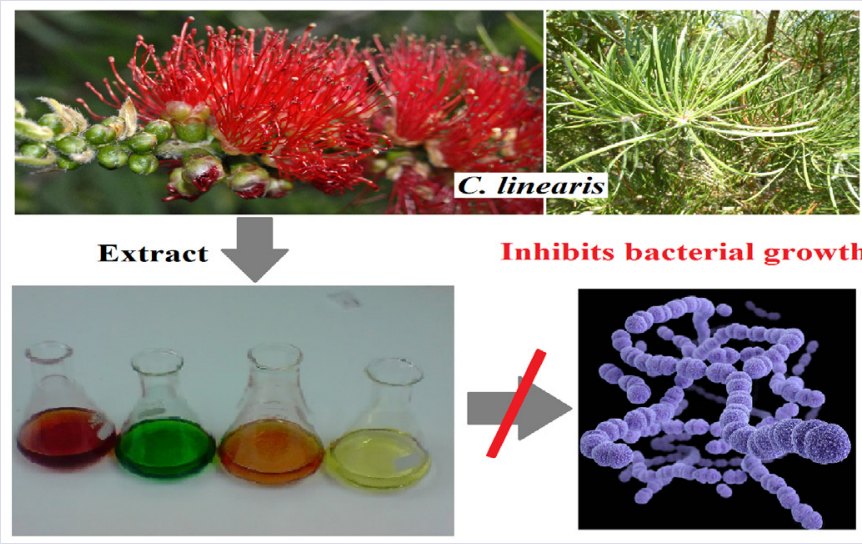

Inhibits bacterial growth

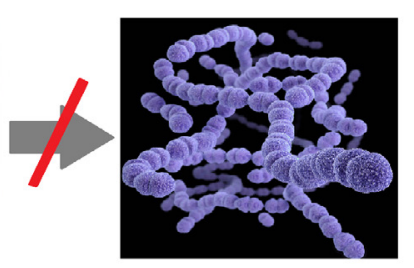

SUMMARY

- Methanolic and aqueous C. linearis leaf extracts were screened for the ability to block the growth of a panel of bacteria.

- The growth inhibition of both gram-positive and gram-negative bacteria was tested.

- The antibacterial activity was quantified by determining the MIC values of each extract.

- Growth time course studies were undertaken against the grampositive bacterial species.

- $\quad$ Toxicity of the C. linearis extracts was determined using the Artemia nauplii toxicity bioassay.

\section{ABOUT AUTHORS}

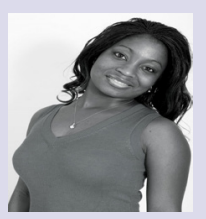

Getmore Rumbudzai Chikowe: Ms Getmore Chikowe completed at BSc Griffith University in life sciences. Following graduation, she undertook a research project in Dr lan Cock's laboratory in the School of Natural Sciences at Griffith University. The project examined the growth inhibitory properties of a variety of Australian native plants against an extensive panel of bacterial pathogens.

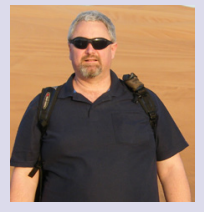

Dr lan Cock leads a research team in the Environmental Futures Research Institute and the School of Natural Sciences at Griffith University, Australia. His research involves bioactivity and phytochemical studies into a variety of plant species of both Australian and international origin, including Aloe vera, South Asian and South American tropical fruits, as well as Australia plants including Scaevola spinescens, Pittosporum phylliraeoides, Terminalia ferdinandiana (Kakadu plum), Australian Acacias, Syzygiums, Petalostigmas and Xanthorrhoea johnsonii (grass trees). This range of projects has resulted in nearly 200 publications in a variety of peer reviewed journals.

Lindiwe Nomathemba Mpala: Ms Lindiwe Mpala completed BSc at Griffith University in life sciences. Following graduation, she undertook a research project in Dr lan Cock's laboratory in the School of Natural Sciences at Griffith University. The project examined the growth inhibitory properties of a variety of Australian native plants against an extensive panel of bacterial pathogens. 